\title{
THE CONTINGENCY OF AGROLANDSCAPES ACCORDING TO ECOLOGICAL-AGROCHEMICAL INDICES AND PERSPECTIVES OF SELECTING TRADITIONAL AGRICULTURAL CROPS IN EASTERN PODILLIA, UKRAINE
}

\section{Valentina Shcherbina ${ }^{1}$ \\ Maxim Ganchuk ${ }^{2}$}

DOI: https://doi.org/10.30525/978-9934-588-15-0-139

Abstract. The paper considers spatial and temporal dynamics of mobile forms of phosphorus, nitrogen, potassium, $\mathrm{pH}$, and humus content in agrocoenoses soils of Eastern Podillia. The contingency of administrative districts of Vinnytsia Region is represented according to the Sorensen-Chekanovsky coefficient based on the studied ecological-agrochemical indices of agricultural lands. The compliance of ecological-agrochemical indices of Eastern Podilian soils with the optimal parameters required for the growth of priority agricultural crops are analysed by the example of the wheat, sunflower, maize and sugar beet. A joint analysis of ecological-agrochemical soil indices shows substantial dynamics of contingency coefficients of administrative districts of Vinnytsia Region. Given the ecological valence of different agricultural crops according to the proposed set of ecological and agrochemical indices, different coefficient values are recorded that indirectly reflect the degree of area suitability for the corresponding plants cultivation. From the list of traditionally grown crops, the wheat meets the greatest degree of compliance with the proposed soil indices. Next in rank come the sunflower, maize, and sugar beet, respectively. This fact should be taken into account when planning the selection of agricultural plants in the region as a whole and in an individual administrative district in particular.

\footnotetext{
${ }^{1}$ Candidate of Biological Sciences,

Associate Professor at Department of Geoecology and Land Management, Tavria Dmytro Motornyi State Agrotechnological University, Ukraine

${ }^{2}$ Assistant at Department of Geoecology and Land Management,

Tavria Dmytro Motornyi State Agrotechnological University, Ukraine

(C) Valentina Shcherbina, Maxim Ganchuk
} 


\section{Introduction}

The rational use and protection of natural resources is an important factor in the socio-economic development of the country. Environmental problems arise when natural resources are inappropriately used and economic activities are carried out without the introduction of safe production technologies. The acute environmental crisis in many regions is deepening and encompassing all large territories, and may in the future turn into a general environmental and economic catastrophe [39].

As agrolandscapes make up approximately $80 \%$ of the territory of Ukraine, the issue of ensuring the sustainability of agrolandscapes in modern conditions is an urgent problem.

In the context of the sustainable development of the state, agrolandscapes must be resistant to anthropogenic load, ensure sustainable yields at an environmentally acceptable and economically sufficient level, and must stably resist degradation processes, which is achieved by natural influences and special measures to streamline agrolandscapes [40].

In the process of reforming land relations, anthropogenic influence on agroladscapes has increased considerably and the irrationality of land use has increased. The current difficult economic situation of business entities determines, in particular, the direction of land use for obtaining economic benefits in the short term. Thus, in large areas cultivate crops without taking into account the natural conditions and opportunities of specific land, which leads to depletion of soils [41].

Given the unsatisfactory quality of land in Ukraine, which tends to deteriorate, and the international community's focus on global environmental issues (desertification, biodiversity conservation, food security), land reform should embrace the internalisation of external effects of land use with particular use of land use [42].

The intensive use of agricultural land without proper environmental justification not only does not ensure the reproduction of soil fertility, but also causes significant disturbances in agroecosystems, leads to a deterioration of the quality of agricultural landscapes, and therefore their degradation [43].

Therefore, the task of ensuring the effective management of land resources should be considered within the broader process of landscape transformation (changing the structure of the land fund) and its negative consequences [42]. 
To date, agricultural production should follow the path of rational use of nature and be oriented to the effective maintenance of its adaptability, sustainability, resource-saving, environmental and environmental role and be based on the maximum use of agro-climatic resources, biological and ecological factors.

In this regard, agro-ecological studies, including those related to the issues of conjugacy of agro-landscapes by ecological-agrochemical parameters and prospects of selection of traditional crops, are of particular importance. The relevance of this subject is primarily determined by prospects of increasing the yield of agricultural crops through studying soil cover of agroecosystems and further selection of the crops taking into account the species tolerance. These manipulations make it possible to group agricultural lands from different areas in accordance with the total set of their studied ecological and agrochemical indices and differentiate them by their "suitability" so as to sow certain plants. Therefore, the relevance of research on this particular subject is indisputable.

The current surveys provided in different countries of the world in the field of studying ecological-agrochemical indices of soil cover, including $\mathrm{pH}[23-24 ; 26]$, nitrogen $[21 ; 35-38]$, potassium $[22 ; 29$; $31-32]$, phosphorus $[20 ; 28 ; 29 ; 33]$ and humus $[25 ; 27 ; 34]$ are multidirectional. Many national scientists were engaged in the research of ecological and agrochemical indices, thanks to which the assessment of growing technologies $[1 ; 6-9 ; 11-12]$, application of fertilizers $[10 ; 13$; $17 ; 19]$, forecasting of yields $[11-12 ; 14-16 ; 18]$ and the optimal ratio of nutrients in the soil for main agricultural crops (winter wheat, sunflower, sugar beet and corn) $[2-5 ; 10]$ have been made for the territory of Ukraine. However, for particular administrative districts the issues of crop selection, aimed at reducing pressure on soil and preserving nutrients, still remain poor studied. Additionally, this subject has never been considered by the example of Eastern Podillia. Though some light has been shed on the problem by now, more detailed elaboration and search for new approaches to its solution including the methods of mathematical analysis are required.

The purpose of the paper is to establish the contingency of agrolandscapes of Eastern Podillia and to determine prospects of planting the main agricultural crops (winter wheat, sunflower, maize, sugar beet) in the region 
on the basis of ecological and agrochemical indices (soil content of humus, nitrogen, phosphorus, potassium, and $\mathrm{pH}$ ).

Objectives: to establish the contingency of agrolandscapes of Eastern Podillia in accordance with ecological and agrochemical indices; to identify the crops which are the most relevant to the proposed ecological and agrochemical soil parameters from the list of traditionally planted crops.

\section{Material and methods}

The paper is based on the original studies carried by the authors in Eastern Podillia during 2008-2012 and 2013-2017.

Prior to sampling, the objectives and the degree of required accuracy of the expected results were determined. Samples were taken during the growing season not earlier than 2 months after fertilization. Sampling points were selected so as to avoid the influence of extraneous factors. On arable lands, cluster samples were taken at a depth of $0-10$ and $15-25 \mathrm{~cm}$ of the arable layer. The cluster sample consisted of 20 point samples. The sample weight was not less than $1 \mathrm{~kg}$. From the samples taken, visible remains of vegetation and foreign impurities were removed.

The laboratory analysis of samples included a set of proper manipulations required to determine such indices as $\mathrm{pH}$, mobile forms of nitrogen, phosphorus, potassium, and humus content. To calculate $\mathrm{pH}$, a soil suspension was prepared in a fivefold volume of $1 \mathrm{~mol} / \mathrm{L}$ potassium chloride $(\mathrm{KCl})$ solution in water. Then $\mathrm{pH}$ of the suspension was measured using a $\mathrm{pH}-\mathrm{me}-$ ter. The content of organic matter in soils was assessed by the oxidometric method. The nitrogen content in the soil was evaluated using the titrimetric method.

To determine the content of phosphorus and potassium compounds in the soil, an extract was prepared (the soil sample was placed in a conical flask adding $100 \mathrm{~cm}^{3}$ of the extracting solution; then the solution was stirred and remained in the vertical position for 18-20 hours). To determine the phosphorus, a reagent was added to the soil sample in a volume of $45 \mathrm{~cm}^{3}$ and the photometry was carried out. The determination of potassium was carried out by flame photometry.

To analyse the results basis the Sorensen-Chekanovsky coefficient was calculated, used for further design of corresponding graphic models. 


\section{Results and discussion \\ 3.1. Agrolandscape ontingency by ecological \\ and agrochemical parameters within the Eastern Podillia}

The area of Eastern Podillia (Vinnytsia Region) is located within the Podillia-Dnieper Territory of the forest-steppe zone of Ukraine. A significant part of Eastern Podillia is occupied by the Podilian structural-denudation upland correspondent to the slopes of the Ukrainian crystal shield that descends south-west. Podilian Upland is heavily indented by valleys of numerous small rivers and ravines. Though it does not represent a continuous plane surface, flat areas are typical for all its watercourses.

The soil cover of Vinnytsia Region has been formed under the impact of a temperate continental climate characterized by fluctuations in the annual temperature regime within $7-9{ }^{\circ} \mathrm{C}$, annual solar radiation at the level of $4300-4400 \mathrm{MJ} / \mathrm{m} 2$, precipitation in the range of 569-639 mm, and a humidity factor of 1.8 .

The main soil-forming rocks are loess and loess-like loam, which granulometric composition varies from light loam in the north to medium loam in the centre and heavy loam in the south of the area. Their characteristic feature is low humus content and sufficiently high thickness of the humus horizon.

Vinnytsia Region is dominated by grey forest soils $-50.5 \%$ and chernozems $-42.1 \%$. The podzolized grey and dark grey soils, podzolized chernozems are the most fertile. They contain $3.5-5.5 \%$ of humus and occupy $1.7 \%$ of Eastern Podillia.

The land resources of Vinnytsia Region consist of 2,649.2 thousand hectares, including $76.1 \%$ (2,016.5 thousand ha) of agricultural lands and $13.3 \%$ (379.1 thousand ha) of forests. The rest is occupied by developed lands $(4 \%)$, open swampy areas $(1.1 \%)$, open areas without vegetation cover or with insignificant vegetation cover $(0.9 \%)$, and others $(1.9 \%)$.

According to the results of the laboratory analysis of soil samples of the studied agrocoenoses of Eastern Podillia, the dynamics of the corresponding ecological-agrochemical indices (Table 1) was found, showing the spatial-temporal heterogeneity of values of $\mathrm{pH}$, mobile forms of nitrogen, phosphorus, potassium, and humus content.

Comparison of average indices for the proposed time intervals (2008-2012 and 2013-2017), taking into account the administrative-ter- 
ritorial division of the Vinnytsia Region, indicates that the values of $\mathrm{pH}$ $(\bar{x}=5.6)$ and humus content $(\bar{x}=2.7 \%)$ remains at the same level, though the range of their dynamics is slightly different. Thus, in the period from 2008 to 2012 , the minimum $\mathrm{pH}$ was equaled to 5.1, maximum -6.2 ; in 2012-2017 the minimum $\mathrm{pH}$ was 5.0, maximum -6.3 . The minimum value of humus in 2008-2012 was $1.84 \%$, maximum $-3.89 \%$. Next five years (2013-2017) showed that the $\mathrm{h}$ - umus content varied from $1.9 \%$ to $3.75 \%$.

The average values of mobile forms of nitrogen, potassium and phosphorus differ between the studied periods showing a clearly expressed decreasing trend in 2008-2012 (mobile forms of nitrogen $\bar{x}=79.0 \mathrm{mg} / \mathrm{kg}$, phosphorus $\bar{x}=79.7 \mathrm{mg} / \mathrm{kg}$, potassium $\bar{x}=99.5 \mathrm{mg} / \mathrm{kg}$ ) and increasing in 2013-2017 (mobile forms of nitrogen $\bar{x}=82.0 \mathrm{mg} / \mathrm{kg}$, phosphorus $\bar{x}=3.5 \mathrm{mg} / \mathrm{kg}$, potassium $\bar{x}=109.9 \mathrm{mg} / \mathrm{kg}$ ).

In 2012-2017 the maximum of average nitrogen values was recorded in Koziatyn District ( $\bar{x}=111.0 \mathrm{mg} / \mathrm{kg}$ ), minimum - in Zhmerynka District $(\bar{x}=64.0 \mathrm{mg} / \mathrm{kg})$; the minimum values of phosphorus were found in Chernivtsi District $(\bar{x}=54.0 \mathrm{mg} / \mathrm{kg})$, maximum - in Orativ District ( $\bar{x}=110.0 \mathrm{mg} / \mathrm{kg}$ ); potassium content ranged from $77.0 \mathrm{mg} / \mathrm{kg}$ (Lypovets District) to $146.0 \mathrm{mg} / \mathrm{kg}$ (Kryzhopil District).

Results of the cluster analysis according to the Sorensen-Chekanovsky quantitative coefficient allow distinguishing the districts of Eastern Podillia into 5 groups based on the average values $(\mathrm{pH}$, content of mobile forms of potassium, nitrogen, phosphorus and humus), which dynamics has been monitored over 5 years from 2008 to 2012 . Each of these groups includes the districts as follows:

- Bar, Sharhorod, Bershad, Illintsi, Orativ, and Teplyk;

- Haisyn, Zhmerynka, Tomashpil, Nemyriv, and Lityn;

- Vinnytsia, Kalynivka, Lypovets, Koziatyn, Khmilnyk, and Pohrebyshche;

- Kryzhopil, Trostianets, Yampil, Tyvriv, Tulchyn;

- Mohyliv-Podilskyi, Chechelnyk, Murovano-Kurylivetskyi, Pishchanka, and Chernivtsi, shown by a dendrite in Figure 1.

The cooperation of agricultural ecosystems in cluster blocks is dictated not only by agrotechnology of agricultural land cultivation, but also by their geographical location, which is represented by a map compiled according to the results of cluster division of agricultural habitats.

The dynamics of this spectrum of chemical indices shows a relative instability in time (Figure 2). It should be taken into account when devel- 
oping identical approaches to the agricultural crop growing technique in regions with similar ecological-agrochemical indicators so as to differentiate them in time, taking into consideration the dynamic rate of transformation of qualitative and quantitative soil indices. Thus, the averaged monitoring results for 2013-2017, based on the above-mentioned ecological-agrochemical soil indices, demonstrate a different picture of the contingency of administrative districts of the Eastern Podillia, reflected not only in numerical changes of the Sorensen-Chekanovsky coefficient but also in different graphic principle of the relationships between the administrative-territorial units of the study area.

\subsection{Prospects for the selection of traditional crops within the Eastern Podillia, taking into account their ecological tolerance to a given set of agrochemical soil parameters}

Analysis of the literature data $[1-5 ; 8 ; 12]$ with descriptions of optimal variation limits of the ecological-agrochemical indices discussed above for the traditional crops of Eastern Podillia allowed establishing that for the winter wheat the most suitable are the soil acidity limits at the level of 6.3-7.5 ( $\bar{x}=6.9)$, for mobile forms of potassium - from 100 to $130 \mathrm{mg}$ / $\mathrm{kg}(\bar{x}=115 \mathrm{mg} / \mathrm{kg})$, nitrogen $-85 \mathrm{mg} / \mathrm{kg}$, phosphorus $-110-140 \mathrm{mg} / \mathrm{kg}$ ( $\bar{x}=125 \mathrm{mg} / \mathrm{kg})$, humus - about $4 \%$.

When comparing the averages of the optimal limits for the winter wheat cultivation with the actual values obtained during monitoring studies of ecological-agrochemical soil indices in Eastern Podillia for 2013-2017 (Table 1), it can be noted that the values of the SorensenChekanovsky coefficients vary from 78 to $93 \%$ (Figure 3). It suggests the good prospects of growing this crop in the region (taking into account the values of the studied soil indices and not taking into account other ecological-agrochemical indices and other environmental factors of the study area). The optimal ratio of the established ecological-agrochemical indices and the averages of optimal limits for the winter wheat cultivation were recorded in Teplyk (92\%), Bar, Orativ and Khmilnyk districts (91\% each). Lityn, Murovano-Kurylivetskyi (78\% each), Chernivtsi, Mohyliv-Podilskyi (79\% each) and Lypovets (80\%) districts had the least coefficient value and were, correspondingly, less suitable for the winter wheat cultivation according to the ecological-agrochemical indices. 


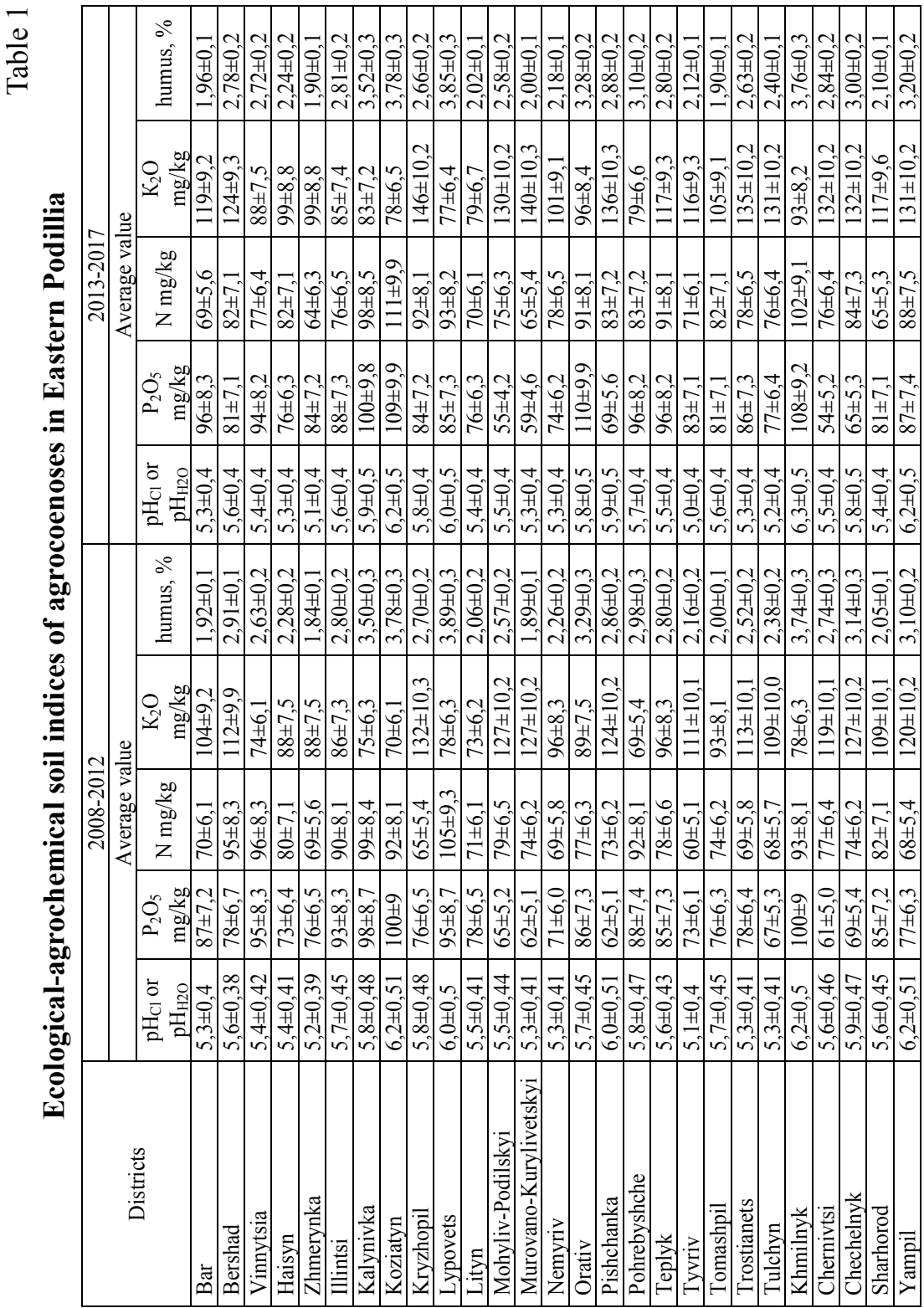



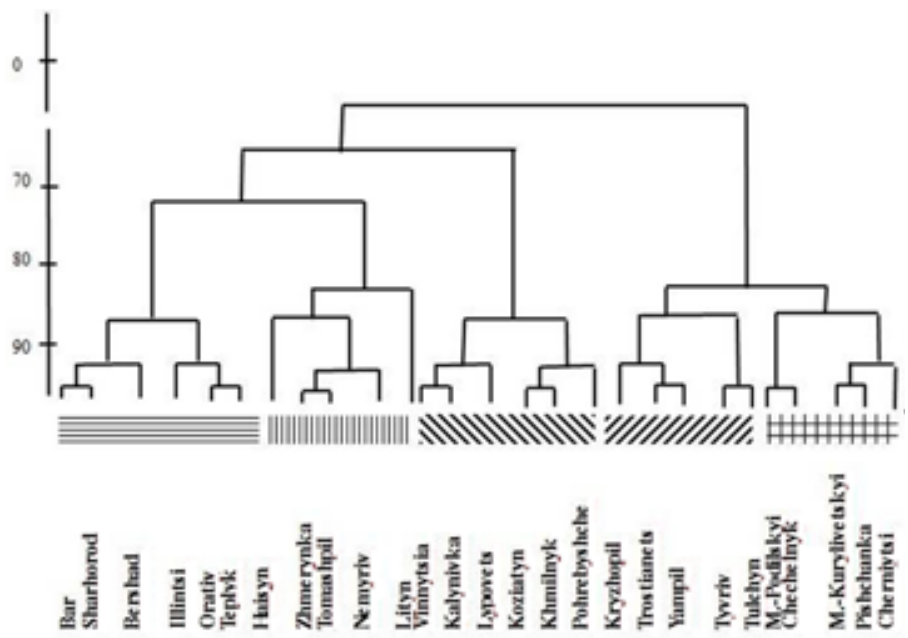

A

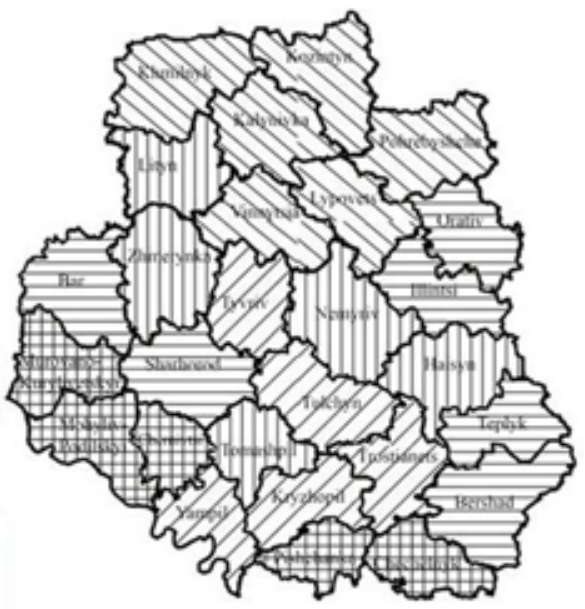

B

Figure 1. Graphic (A) and cartographic (B) models of contingency of administrative districts of Vinnytsia Region according to the Sorensen-Chekanovsky coefficient based on the studied ecological-agrochemical soil indices of agrocoenoses (2008-2012) 

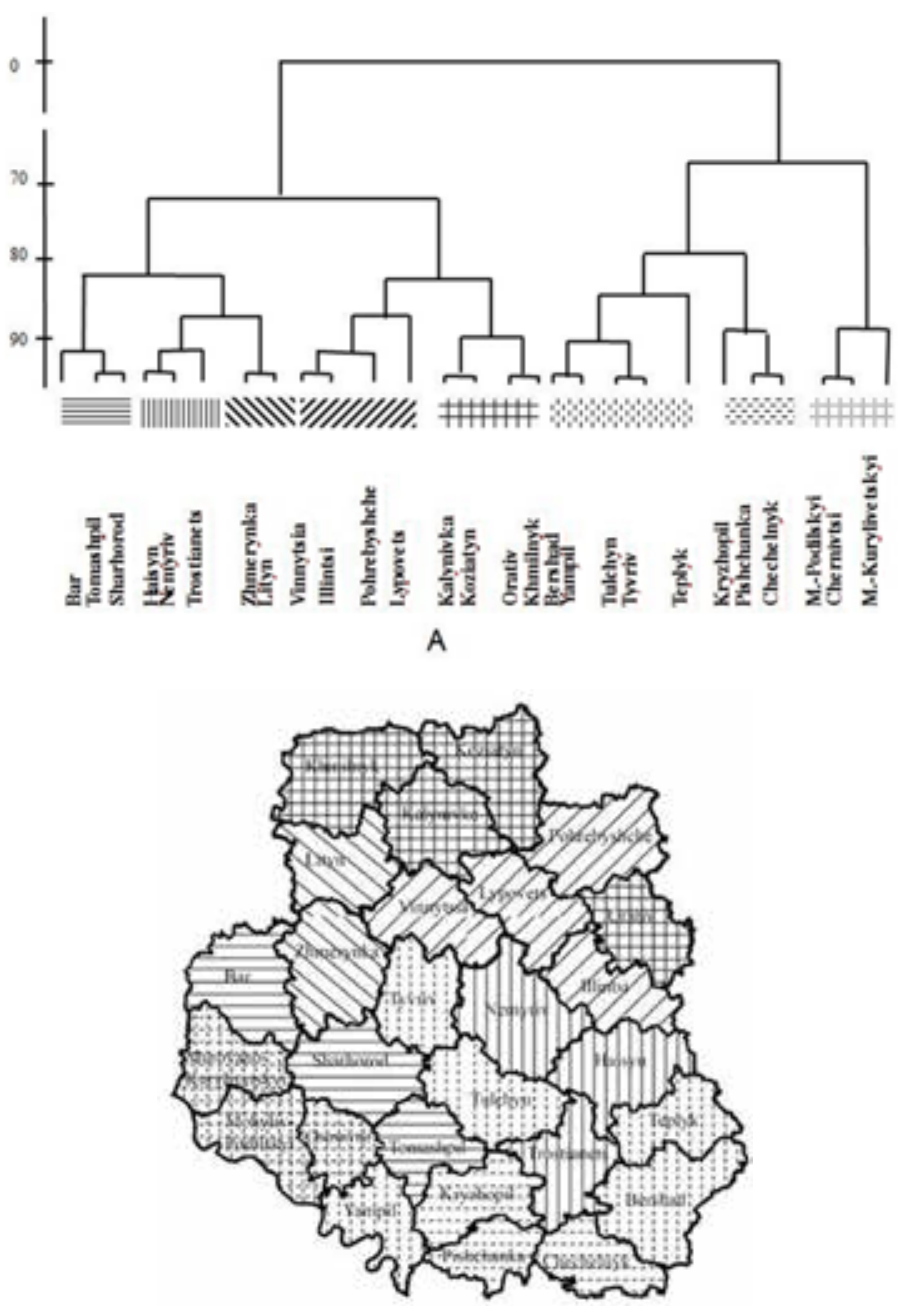

B

Figure 2. Graphic (A) and cartographic (B) models of contingency of administrative districts of Vinnytsia Region according to the Sorensen-Chekanovsky coefficient based on the studied ecological-agrochemical soil indices of agrocoenoses (2013-2017) 
For the sunflower, soil acidity at the level of 6-6.8 $(\bar{x}=6.4)$ are the most suitable, the content of mobile forms of potassium - from 120 to $140 \mathrm{mg} / \mathrm{kg}$ $(\bar{x}=130 \mathrm{mg} / \mathrm{kg})$, phosphorus $-100-110 \mathrm{mg} / \mathrm{kg}(\bar{x}=105 \mathrm{mg} / \mathrm{kg})$, humus content should be at the level of $3.5 \%$ [14-15].

Two of the 27 administrative districts of Vinnitsia Region mentioned in the list showed the highest degree of similarity of ecological-agrochemical indices of the sunflower vegetation. These are Yampil and Bar districts for which the Sorensen-Chekanovsky quantitative coefficients make up 95\%. Close to these values are Trostianets, Teplyk (94\% each), Bershad, Tulchyn (93\% each), Kryzhopil (92\%), Orativ, Sharhorod, Khmilnyk, Tyvriv (91\%), Chechelnyk, Pishchanka (90\% each) districts, with percentages varying from 90 to $95 \%$. The range from 85 to $90 \%$ is recorded for Mohyliv-Podilskyi, Tomashpil ( $88 \%$ each), Murovano-Kurylivetskyi, Koziatyn, Kalynivka, Zhmerynka, Vinnytsia, Chernivtsi (87\% each), Nemyriv, Illintsi, Haisyn, Pohrebyshche (85\% each) districts. The less optimal set of the studied ecological-agrochemical indices for the sunflower is found in Lypovets (82\%) and Lityn (79\%) districts (Figure 3).

For the maize, according to the literature data, the variation range of the $\mathrm{pH}$, content of mobile forms of potassium, phosphorus and humus should be kept within 6.0-7.0 ( $\bar{x}=6.5), 130-150 \mathrm{mg} / \mathrm{kg}(\bar{x}=140 \mathrm{mg} / \mathrm{kg})$, $140-150 \mathrm{mg} / \mathrm{kg}(\bar{x}=145 \mathrm{mg} / \mathrm{kg}), 3-4 \%(\bar{x}=3.5 \%)$, respectively [9-11; 13]. Moreover, any changes in the thresholds of the given set of indices inevitably lead to changes in the Sorensen-Chekanovsky coefficients, which, in this case, have the lower limit of $71 \%$ and the upper limit of $87 \%$ (Figure 3 ).

The sugar beet requires soil acidity within 7.0-7.5 $(\bar{x}=7.3)$, the content of mobile forms of potassium - 160-180 mg/ $\mathrm{kg}(\bar{x}=170 \mathrm{mg} / \mathrm{kg})$, phosphorus $-160-180 \mathrm{mg} / \mathrm{kg}(\bar{x}=170 \mathrm{mg} / \mathrm{kg})$ and humus $-3.5 \%$ [16-19].

In accordance with the performed calculations, the threshold values of the indices are set at the level of 63-80\%. The values in Lityn, Lypovets, Illintsi, Haisyn, Pohrebyshche, Nemyriv, Zhmerynka and Kalynivka districts range between 63-70\%; Mohyliv-Podilskyi, Koziatyn, Chernivtsi, Tomashpil, Sharhorod, Chechelnyk, Murovano-Kurylivetskyi, Tyvriv, Bershad, Khmelnyk, Pishchanka, Tulchin, Orativ, Bar, Teplyk, Vinnitsia, Yampil, Trostianets and Kryzhopil shows the coefficient value from 71 to $80 \%$ (Figure 3). 


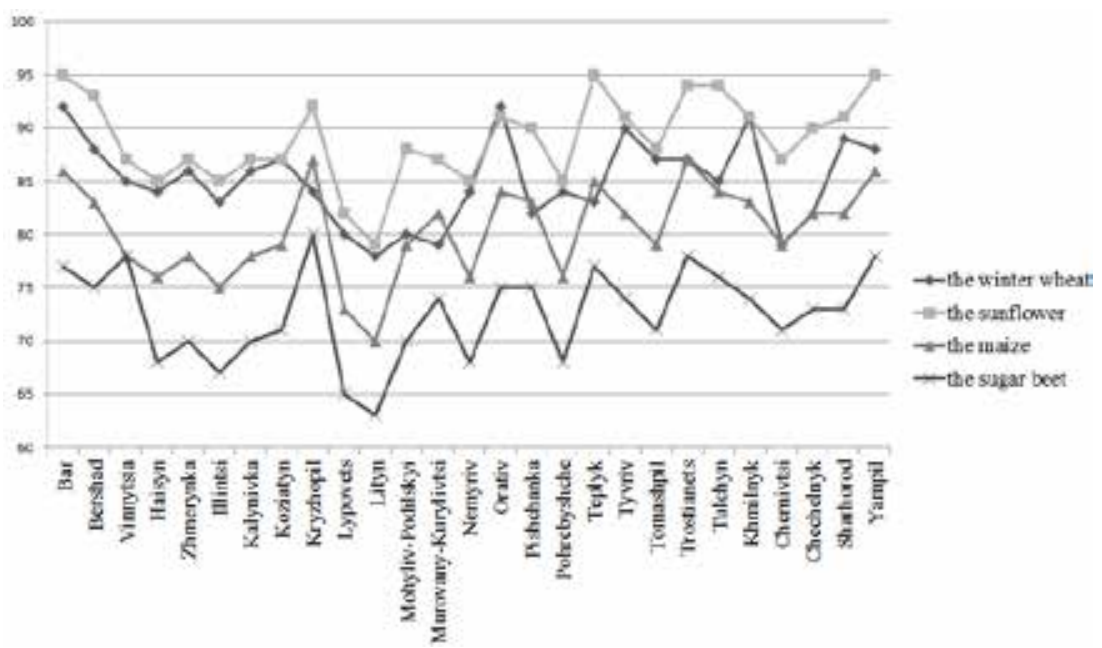

Figure 3. Compatibility of ecological-agrochemical soil indices of Eastern Podillia with the optimal indices required for the winter wheat, the sunflower, the maize, the sugar cultivation (2013-2017)

\section{Conclusions}

The dynamics of $\mathrm{pH}$, mobile forms of nitrogen, phosphorus and potassium, as well as humus content in the soils of agrocoenoses of Eastern Podillia is determined by spatial and temporal coordinates. A joint analysis of the ecological-agrochemical soil indices shows a significant dynamics of the coefficients of contingency of administrative districts of Vinnytsia region.

Given the ecological valence of different agricultural crops according to the proposed set of ecological-agrochemical indices, the different coefficient values are recorded that indirectly reflects the degree of area suitability for the corresponding crops cultivation. Thus, from the list of traditionally grown crops, the wheat is identified as the most compatible with the proposed ecological-agrochemical soil indices. Next in rank come the sunflower, maize and sugar beet, respectively. This fact that should be taken into account when planning the agricultural plant selection in the region as a whole and in an individual administrative district in particular. 


\section{References:}

1. Nazarenko M.M., Lykholat Y.V. (2018). Influence of relief conditions on plant growth and development. Bulletin of the University of Dnepropetrovsk. Geology, Geography, 26(1), 143-149. https://doi.org/10.15421/111815

2. Zhuk O.I. (2013). Rist mizhvuzliv pshenyci za riznyh umov mineral'nogo zhyvlennja [The growth of the wheat internode under different mineral nutrition]. Modern Phytomorphology, 4, 377-381. https://doi.org/10.5281/zenodo.161429 (in Ukrainian)

3. Zhuk O.I. (2016). Rist i produktyvnist' kolosa Triticum aestivum L. za riznyh umov mineral'nogo zhyvlennja [The growth and productivity of the spike of Triticum aestivum L. under different mineral nutrition]. Modern Phytomorphology, 10, 111-116. https://doi.org/10.5281/zenodo.155368 (in Ukrainian)

4. Zhuk O.I. (2014). The stem structure of Triticum aestivum L. under different mineral nutrition. Modern Phytomorphology, 6, 109-113. https://doi.org/10.5281/ zenodo.160463 (in Ukrainian)

5. Ulich O.L., Kostenko N.P., Tkachyk S.O., Hryniv S.M., Zahynailo M.I., Lysikova V.M., Tereshchenko Yu.F. (2015). Vplyv agroekologichnyh umov gruntovo-klimatychnyh makro- $\mathrm{j}$ mikrozon na adaptyvnist' ta produktyvnist' novyh sortiv pshenyci mjakoi' ozymoi' [The impact of agroecological conditions of soil and climatic macro- and microzones on the adaptivity and productivity of new cultivars of the soft winter wheat]. Studying and Management of Cultivars, 1-2 (26-27), 22-26. https://doi.org/10.21498/2518-1017.1-2(26-27).2015.55860 (in Ukrainian)

6. Demydov O.A., Khomenko S.O., Fedorenko I.B., Blyznyuk R.M., Kuzmenko E.A. (2016). Ocinka adaptyvnoi' zdatnosti linij pshenyci jaroi' v umovah Lisostepu Ukrai'ny [Assessment of adaptive capacity of spring wheat lines under conditions of the forest-steppe zone of Ukraine]. Plant Varieties Studying and Protection, 1(30), 57-61. https://doi.org/10.21498/2518-1017.1(30).2016.61778 (in Ukrainian)

7. Korkhova M.M. (2014). Urozhajnist' ta jakist' zerna pshenyci ozymoi' za vyroshhuvannja $\mathrm{v}$ umovah Pivdennogo stepu Ukrai'ny [The productivity and grain quality of the winter wheat during its growing in the southern steppe zone of Ukraine]. Plant Varieties Studying and Protection, 4, 82-86. https://doi.org/10.21498/2518-1017.4(25).2014.55985 (in Ukrainian)

8. Gyrka A.D., Pedash O.O., Kulyk I.O., Viniukov O.O., Ischenko V.A. (2017). Produktyvnist' pshenyci ozymoi' zalezhno vid stroku sivby ta normy vysivu pislja ripaku ozymogo $\mathrm{v}$ umovah stepu [The winter wheat productivity depending on the timing of planting and the sowing norms after the winter rape under steppe conditions]. Ukrainian Journal of Ecology, 7(1), 30-36. http://dx.doi.org/ $10.15421 / 20173$ (in Ukrainian)

9. Fadeev L.V. (2016). Tochnaja agrotehnologyja budushhego nachynaetsja segodnja. Kukuruza [A precise agrotechnology of the future starts today. Maize.] Grain Products and Mixed Fodders, 1, 5-11. http://dx.doi.org/10.21691/gpmf. v61i1.96 (in Ukrainian)

10. Fiala R., Kenderešová L., Syshchyko D.V., Martinka M., Repka V., Pavlovkin J., Čiamporová M. (2013). Comparison of root growth and morphological responses to cadmium and nickel in two maize cultivars. Modern Phytomorphology, 3, 131-137. https://doi.org/10.5281/zenodo.162002 
11. Prysiazhnyuk L.M., Shovhun O.O., Korol L.V., Korovko I.I. (2016). Ocinka pokaznykiv stabil'nosti j plastychnosti novyh gibrydiv kukurudzy (Zea mays L.) v umovah Polissja ta Stepu Ukrai'ny [Assessement of stability and plasticity indices of new maize hybrids (Zea mays L.) in Polissia and the steppe zone of Ukraine]. Plant Varieties Studying and Protection, 2(31) 16-21. https://doi.org/ 10.21498/2518-1017.2(31).2016.70050 (in Ukrainian)

12. Gyrka A.D., Kulyk I.O. (2016). Vplyv normy vysivu nasinnja, stroku sivby ta rezhymu mineral"nogo zhyvlennja na produktyvnist" pshenyci jaroi' v pivnichnomu stepu ukrai'ny [The impact of the seed sowing norm, timing of planting and regime of mineral nutrition on the spring wheat productivity in the northern steppe of Ukraine]. Biological Bulletin of Bohdan Khmelnitskyi Melitopol State Pedagogical University, 6(2), 246-252. http://dx.doi.org/10.15421/201654 (in Ukrainian)

13. Lykhovyd P.V., Lavrenko S.O. (2017). The impact of soil cultivation and mineral fertilizers on the biological soil activity under the maize plantations. Ukrainian Journal of Ecology, 7(4), 18-24. http://dx.doi.org/10.15421/2017_81 (in Ukrainian)

14. Yeremenko O.A., Kalytka V.V., Kalenska S.M. (2017). Vplyv reguljatora rostu na rist, rozvytok roslyn i formuvannja vrozhaju gibrydiv sonjashnyku $\left(\mathrm{F}_{1}\right) \mathrm{v}$ umovah Pivdennogo Stepu Ukrai'ny [The impact of the growth regulator on the plant growth, development and formation of the productivity in the sunflower hybrids $\left(\mathrm{F}_{1}\right)$ under conditions of the southern steppe of Ukraine]. Plant Varieties Studying and Protection, 13(2), 141-149. https://doi.org/10.21498/2518-1017.13.2.2017.105395 (in Ukrainian)

15. Zhukov O.V., Ponomarenko S.V. (2017). Agroekologichni aspekty prostorovo-chasovoi' dynamiky urozhajnosti sonjashnyku [Agroecological aspects of the temporal-spatial dynamics of the sunflower productivity]. Ukrainian Journal of Ecology, 7(3), 186-207. http://dx.doi.org/10.15421/2017_68 (in Ukrainian)

16. Tarabrin O.E., Semenov A.V. (2005). Urozhajnist" ta jakist" nasinnja burjaku zalezhno vid chekanky [The productivity and quality of beet seeds in relation to their embossing]. Plant Varieties Studying and Protection, 2, 125-131. https://doi.org/10.21498/2518-1017.2.2005.67540 (in Ukrainian)

17. Kartsev Yu.G. (2000). Vlijanie vozrastajushhih doz udobrenij i sootnoshenija azota, fosfora i kalija na produktivnost' i soderzhanie sahara $v$ svekle. [The impact of increasing doses of fertilizers and the ratio of nitrogen, phosphorus and potassium on the productivity and sugar content of the beetroots.] Transactions of All-Russian Scientific Research Institute of Agrochemistry, 61, 7-10. (in Russian)

18. Olenyuk A.M. (2008). Fizychni vlastyvosti g'runtu ta produktyvnist' cukrovyh burjakiv. [Physical soil properties and the sugar beet productivity]. Transactions of Podilian State Agrarian Engineering University, 16, 132-135. (in Ukrainian)

19. Tsvey Ya.P., Torlina O.M. (2016). Chernozemnoe plodorodie v svjazi s oplodotvoreniem saharnoj svekly [Chernozem fertility in relation to the sugar beet fertilization] Balanced Use of Nature Resources, 2, 151-155. (in Russian)

20. Amin Soltangheisi, Marcos Rodrigues, Marta Jordana Arruda Coelho, Andressa Marcon Gasperini, Laércio Ricardo Sartor, Paulo Sergio Pavinato (2018). Changes in soil phosphorus lability promoted by phosphate sources and cover crops. 
Soil and Tillage Research, Volume 179, Pages 20-28. https://doi.org/10.1016/ j.still.2018.01.006

21. Cecilia A. Pérez, Juan J. Armesto (2018). Coupling of microbial nitrogen transformations and climate in sclerophyll forest soils from the Mediterranean Region of central Chile. Science of The Total Environment, Volume 625, Pages 394-402. https://doi.org/10.1016/j.scitotenv.2017.12.306

22. Chakkrit Poonpakdee, Jing-Hua Tzeng, Chih-Huang Weng, Yao-Tung Lin (2018). Assessment of potassium speciation in soil using traditional single leaching and modified sequential extraction processes. Journal of Soils and Sediments, Volume 18, pp. 610-623. doi: 10.1007/s11368-017-1773-6

23. Dan Xiao, Yuan Huang, Shuzhen Feng, Yunhui Ge, Wei Zhang, Xunyang He, Kelin Wang (2018). Soil organic carbon mineralization with fresh organic substrate and inorganic carbon additions in a red soil is controlled by fungal diversity along a $\mathrm{pH}$ gradient. Geoderma, Volume 321, Pages 79-89. https://doi.org/10.1016/j.geoderma.2018.02.003

24. Enqing Hou, Dazhi Wen, Yuanwen Kuang, Jing Cong, Chengrong Chen, Xianjin He, Marijke Heenan, Hui Lu, Yuguang Zhang (2018). Soil pH predominantly controls the forms of organic phosphorus in topsoils under natural broadleaved forests along a $2500 \mathrm{~km}$ latitudinal gradient. Geoderma, Volume 315, Pages 65-74. https://doi.org/10.1016/j.geoderma.2017.11.041

25. Juan Zhang, Shu-kai Fan, Ming-hua Zhang, Michael L. Grieneisen, Jianfeng Zhang (2018): Aliphatic hydrocarbons recovered in vegetables from soils based on their in-situ distribution in various soil humus fractions using a successive extraction method. Journal of Hazardous Materials, Volume 346, Pages 10-18. https://doi.org/10.1016/j.jhazmat.2017.12.012

26. Jun Shan, Pinpin Yang, Xiaoxia Shang, M. Mizanur Rahman, Xiaoyuan Yan (2018). Anaerobic ammonium oxidation and denitrification in a paddy soil as affected by temperature, $\mathrm{pH}$, organic carbon, and substrates. Biology and Fertility of Soils, Volume 54, pp 341-348. https://doi.org/10.1016/j.soilbio.2015.08.040

27. Marchela Pandelova, Bernhard Henkelmann, Bernd M. Bussian, KarlWerner Schramm (2018). Results of the second national forest soil inventory in Germany - Interpretation of level and stock profiles for PCDD/F and PCB in terms of vegetation and humus type. Science of The Total Environment, Volumes 610-611, Pages 1-9. https://doi.org/10.1016/j.scitotenv.2017.07.246

28. Maximilian Koch, Jens Kruse, Bettina Eichler-Löbermann, Dana Zimmer, Sabine Willbold, Peter Leinweber, Nina Siebers (2018). Phosphorus stocks and speciation in soil profiles of a long-term fertilizer experiment: Evidence from sequential fractionation, $\mathrm{P} K$-edge XANES, and ${ }^{31} \mathrm{P}$ NMR spectroscopy. Geoderma, Volume 316, Pages 115-126. https://doi.org/10.1016/j.geoderma.2017.12.003

29. Nathane M.S. Vilela, Michael S. Thebaldi, Bruno De P. Leal, Ascânio V. Silva, Ivani P. Martins (2018). Transport parameters of potassium from different sources in soil columns. English Agriculture, vol. 38, no. 1. http://dx.doi.org/10.1590/1809-4430-eng.agric.v38n1p135-141/2018

30. Nele Meyer, Gerhard Welp, Andrei Rodionov, Nils Borchard, Christopher, Martius, Wulf Amelung (2018). Nitrogen and phosphorus supply controls soil organic 
carbon mineralization in tropical topsoil and subsoil. Soil Biology and Biochemistry, Volume 119, Pages 152-161. https://doi.org/10.1016/j.soilbio.2018.01.024

31. Przemysław Barłóg, Witold Grzebisz, Remigiusz Łukowiak (2018). Faba bean yield and growth dynamics in response to soil potassium availability and sulfur application. Field Crops Research, Volume 219, Pages 87-97. https://doi.org/10.1016/j.fcr.2018.01.027

32. Sirous Shakeri, Seyed A. Abtahi (2018). Potassium forms in calcareous soils as affected by clay minerals and soil development in Kohgiluyeh and BoyerAhmad Province. Southwest Iran Journal of Arid Land, Volume 10, pp. 217-232. https://doi.org/10.1007/s40333-018-0052-8

33. Theresa Zicker, Sabinevon Tucher, Mareike Kavka, Bettina EichlerLöbermann (2018). Soil test phosphorus as affected by phosphorus budgets in two long-term field experiments in Germany. Field Crops Research, Volume 218, Pages 158-170. https://doi.org/10.1016/j.fcr.2018.01.008

34. Tobiašová E., Barančíková G., Gömöryová E., Dębska B., Banach-Szott M. (2018). Humus substances and soil aggregates in the soils with different texture. Soil \& Water Research, 13: 44-50. https://doi.org/10.17221/31/2017-SWR

35. Vijay Singh Meena, Tilak Mondal, Brij Mohan Pandey, Anirban Mukherjee, Ram Prakash Yadav, Mahipal Choudhary, Sher Singh, Jaideep Kumar Bisht, Arunava Pattanayak (2018). Land use changes: Strategies to improve soil carbon and nitrogen storage pattern in the mid-Himalaya ecosystem, India. Geoderma, Volume 321, Pages 69-78. https://doi.org/10.1016/j.geoderma.2018.01.017

36. Yanxia Nie, Mengcen Wang, Wei Zhang, Zhuang Ni, Yasuyuki Hashidoko, Weijun Shen (2018). Ammonium nitrogen content is a dominant predictor of bacterial community composition in an acidic forest soil with exogenous nitrogen enrichment. Science of The Total Environment, Volume 624, Pages 407-415. https://doi.org/10.1016/j.geoderma.2018.02.002

37. Yefeng Jiang, Lei Rao, Kai Sun, Yi Han, Xi Guo (2018). Spatio-temporal distribution of soil nitrogen in Poyang lake ecological economic zone (SouthChina). Science of The Total Environment, Volume 626, Pages 235-243. https://doi.org/10.1016/j.scitotenv.2018.01.087

38. Yiming Xu, Scot E. Smith, Sabine Grunwald, Amr Abd-Elrahman, Suhas P. Wani (2018). Effects of image pansharpening on soil total nitrogen prediction models in South India. Geoderma, Volume 320, Pages 52-66. https://doi.org/ 10.1016/j.geoderma.2018.01.017

39. Bryndzya O. (2014). Metodychni polozhennja ekologo-ekonomichnogo ocinjuvannja sil's'kogospodars'kogo zemlekorystuvannja na landshaftnij osnovi [Methodical statutes of ekological and economical estimation of agricultural lands use based on landscape]. Galician Economic Bulletin. Ternopil: TNTU, Tom 45. № 2. P. 5-9. (in Ukrainian)

40. Artamonov V., Mihno P., Vasilenko M. (2019). Oznaky stijkosti agrolandshaftu [Agility agrolandscape characteristics]. Prospects for Institutional Development of Land Relations in Ukraine: Proceedings of the All-Ukrainian Scientific and Practical Conference (May 21-May 22, 2019). Poltava: PNTU, pp. 36-37. (in Ukrainian) 
41. Kalenska O. (2015). Suchasnyj stan agrolandshaftiv Chernivec'koi' oblasti [The current state of agrolandscapes in Chernivtsi region]. Proceedings of the conference of the 5th All-Ukrainian Congress of Ecologists, September 23-26. VNTU, p. 207. (in Ukrainian)

42. Kalenska O., Sakal O. (2015). Suchasnyj stan agrolandshaftiv Chernivec'koi' oAgrolandshafty: ponjattja, sub'jekty i faktory transformacii'blasti [Cultivated lands: concept, subjects and factors of transformation]. Economist, no 3, pp. 26-29. (in Ukrainian)

43. Podzeriy R. (2011). Antropogennyj vplyv na agrolandshafty Cherkas'koi' oblasti [Anthropogenic impact on agrolandscapes of Cherkasy region]. Problems of reproduction and protection of biodiversity of Ukraine. Proceedings of the All-Ukrainian Scientific and Practical Conference. Poltava: Astraya, pp. 193-95. (in Ukrainian) 